\title{
The early outcome of thrombolytic treatment in ischaemic stroke patients: a retrospective analysis
}

\section{Wczesne wyniki leczenia trombolitycznego pacjentów z udarem niedokrwiennym mózgu - analiza retrospektywna}

\author{
Dariusz Kotlęga ${ }^{1}$, Agnieszka Meller ${ }^{1}$, Monika Gołąb-Janowskaํㅜ, Wioletta Pawlukowska², Przemysław Nowacki ${ }^{1}$ \\ ${ }^{1}$ Department of Neurology, Pomeranian Medical University, Szczecin, Poland \\ Head of the Department: Prof. Przemysław Nowacki MD, PhD \\ 2Department of Medical Rehabilitation and Clinical Physiotherapy, Pomeranian Medical University, Szczecin, Poland \\ Head of the Department: Prof. Iwona Rotter MD, PhD
}

Key words: treatment outcome, stroke, tissue plasminogen activator, patient outcome assessment,

Słowa kluczowe: wynik leczenia, udar, tkankowy aktywator plazminogenu, ocena wyniku leczenia.

\begin{abstract}
Introduction: The results of early outcome in thrombolysed stroke patients are connected with the long-term effect measured as disability and death rate. There are different definitions of the early improvement in such patients.

Aim of the research: To establish potential prognostic factors adversely influencing the early outcome of stroke patients treated with alteplase.

Material and methods: The analysis of 245 consecutive ischaemic stroke patients treated intravenously with recombinant tissue plasminogen activator (rt-PA) was conducted. The outcome was analysed $24 \mathrm{~h}$ after rt-PA treatment depending on the NIHSS score. Group I consisted of 105 patients with the improvement in NIHSS $\geq 2$ points $24 \mathrm{~h}$ after intravenous rt-PA administration, and group II comprised of the rest of the patients $(n=140)$.

Results: The independent factors adversely affecting the early outcome were: hypertension, old ischaemic lesions in initial brain computed tomography (CT), longer therapeutic window, higher baseline NIHSS (respectively: OR $=0.34, p<0.05$; $\mathrm{OR}=0.55, p<0.01 ; \mathrm{OR}=0.99, p<0.01 ; \mathrm{OR}=0.91, p<0.01$ )

Conclusions: There are factors affecting the grade of early neurological improvement assessed $24 \mathrm{~h}$ after rt-PA therapy that may help to improve the efficacy of the acute phase treatment and secondary prevention of stroke patients. More attention should be paid to patients with hypertension, those with greater initial neurological deficit, longer onset-to-treatment time, and old ischaemic changes in initial brain CT.
\end{abstract}

\section{Streszczenie}

Wprowadzenie: Wyniki wczesnego leczenia trombolitycznego pacjentów z udarem niedokrwiennym mózgu wiążą się z długotrwałym efektem w zakresie niepełnosprawności i śmiertelności. Spotykane są różne definicje wczesnej poprawy w tej grupie pacjentów.

Cel pracy: Ustalenie potencjalnych czynników prognostycznych niekorzystnie wpływających na wczesny wynik leczenia alteplazą pacjentów z udarem mózgu.

Materiał i metody: Analizie poddano 245 kolejnych pacjentów z rozpoznaniem udaru niedokrwiennego mózgu leczonych dożylnie rekombinowanym tkankowym aktywatorem plazminogenu (rt-PA). Wynik oceniono 24 godziny po zastosowaniu leczenia w zależności od wyniku wg skali NIHSS. Grupę I stanowiło 105 pacjentów ze stopniem poprawy $\geq 2$ pkt wg skali NIHSS w czasie 24 godzin po leczeniu, a grupę II - pozostali pacjenci $(n=140)$.

Wyniki: Niezależnymi czynnikami ryzyka niekorzystnie wpływającymi na wczesny wynik leczenia są: nadciśnienie tętnicze, stare zmiany niedokrwienne mózgu, dłuższe okno terapeutyczne, wyższy wyjściowo wynik wg skali NIHSS (odpowiednio: $\mathrm{OR}=0,34, p<0,05 ; \mathrm{OR}=0,55, p<0,01 ; \mathrm{OR}=0,99, p<0,01 ; \mathrm{OR}=0,91, p<0,01$ ).

Wnioski: Znane są czynniki, które wpływają na stopień wczesnej poprawy neurologicznej ocenianej w czasie 24 godzin po leczeniu trombolitycznym. Mogą one pomóc w poprawie skuteczności terapii ostrej fazy i profilaktyki wtórnej u pacjentów z udarem niedokrwiennym mózgu. Należy poświęcać więcej uwagi pacjentom z nadciśnieniem tętniczym, wyjściowo większym deficytem neurologicznym, z dłuższym oknem terapeutycznym oraz ze starymi zmianami naczyniowymi mózgu. 


\section{Introduction}

A recombinant tissue plasminogen activator (rt-PA) was approved by the Food and Drug Administration (FDA) based on the results of the National Institute of Neurological Disorders and Stroke (NINDS) trial in 1996 for ischaemic stroke treatment [1]. Tissue type plasminogen activator is more clot specific which means that it promotes the conversion of plasminogen to plasmin only when bound to fibrin in a thrombus [2]. Intravenous thrombolysis with rt-PA improves functional neurological outcome and reduces mortality in acute ischaemic stroke [3]. The proportion of patients who benefit from thrombolysis by at least one point on the modified Rankin Scale (mRS) has been calculated to $32 \%$ [4]. It was shown that $40.6 \%$ of stroke patients treated with rt-PA had a 3-month $\mathrm{mRS}$ score $\leq 1$ [5]. A beneficial effect is also observed after 1 year, with a disability reduction of $30 \%$. Rt-PA decreases the relative risk of death or disability after 3 months by $13 \%$. The recommended therapeutic window is $4.5 \mathrm{~h}$ after stroke onset [6-8].

There are prognostic factors of thrombolytic treatment in stroke [9]. The early neurological improvement may also be an important factor indicating the outcome. There have been diverse definitions used to describe the rapid recovery. In one study the rapid neurological recovery was defined as an improvement of at least $50 \%$ within $24 \mathrm{~h}$ measured by the National Institute of Health Stroke Scale (NIHSS) and was correlated with favourable outcome at 3 months [10]. Other authors defined an early neurological improvement as the NIHSS score between 0 and 4 at $24 \mathrm{~h}$. Patients with worsening in neurological deficit (i.e. increase in NIHSS $\geq 1$ point) had worse outcome at 3 months [11]. The quartiles of 24-hour NIHSS score strongly predict the 3-12-month outcome and quality of life index [12]. In a recent study very early improvement was analysed defined as the difference between baseline and 2-hour NIHSS score (very early post-randomisation improvement - VEPRIM) in relation to 3-month outcome, and decreased risk of death and symptomatic intracerebral haemorrhage $(\mathrm{SICH})$ [13]. The neurological improvement during the first $24 \mathrm{~h}$ after thrombolysis was a strong predictor of favourable outcome at 3 months also in other studies [14-16]. Moreover, an improvement in NIHSS scale observed at 15 and $30 \mathrm{~min}$ after the rt-PA infusion predicts outcome at 3 months [17]. Other authors defined improvement as the NIHSS score improvement by $40 \%$ from baseline and compared patients at $1 \mathrm{~h}$ after thrombolysis (very early neurological improvement - VENI) and at $24 \mathrm{~h}$ (early neurological improvement - ENI) [18]. Early neurological improvement was also defined as eight or more points in NIHSS $24 \mathrm{~h}$ after thrombolysis while neurological improvement was defined as an improvement of at least eight points at discharge (compared with baseline) [19].
As presented above, different settings are used to assess early improvement. In our study we assessed early neurological improvement $24 \mathrm{~h}$ after rt-PA treatment, concentrating on the in-hospital factors that can potentially be detected and effectively treated, because they affect the long-term outcome.

\section{Aim of the research}

The aim of the study was to establish unfavourable prognostic factors influencing the in-hospital outcome in stroke patients treated with rt-PA.

\section{Material and methods}

A retrospective analysis of 245 consecutive ischaemic stroke patients treated intravenously with rt-PA was conducted. Subjects were hospitalised in the Department of Neurology.

The outcome was analysed in two groups $24 \mathrm{~h}$ after rt-PA treatment, depending on the NIHSS score: group I consisted of 105 patients with the improvement in NIHSS $\geq 2$ points $24 \mathrm{~h}$ after intravenous rt-PA administration, and group II comprised of the rest of the patients (140 individuals): with no improvement, improvement $<2$ points, or with deterioration.

The NIHSS score was assessed initially before treatment (NIHSS I) and $24 \mathrm{~h}$ after (NIHSS II) according to the definition [20]. The initial systolic (SBP) and diastolic blood pressure (DBP) were measured just after admission to the hospital.

The rest of the analysed factors were obtained from the history and medical records or diagnosed during hospitalisation, including: hypertension, coronary heart disease, myocardial infarction, atrial fibrillation, type 2 diabetes mellitus, smoking, past stroke/ transient ischaemic attack (TIA), significant stenosis of internal carotid artery ( $\geq 70 \%$ ), previous use of antiplatelet or oral anticoagulant treatment, previous antihypertensives, occupation (blue and white collar), age, sex, body mass index, initial body temperature, serum C-reactive protein (CRP), white blood cells count, fibrinogen, and haematocrit. Ultrasonography of the carotid arteries was performed with a GE LOGIQBook XP camera, linear head $7.5 \mathrm{MHz}$, and Esaote MyLab Twice linear head $7.5 \mathrm{MHz}$. Particular definitions are given elsewhere [21]. The date and time of admission to the hospital with special consideration to the weekend were also taken into account. Based on initial brain computed tomography (CT) the presence of previous ischaemic changes and acute ischaemic damage were assessed. The therapeutic window was the period between the onset of the symptoms and the time the rt-PA administration was started.

The initial factors (NIHSS, body temperature, blood pressure, brain CT) mean those assessed on the Emergency Unit directly before admission to the Neurology Department. 


\section{Statistical analysis}

Statistical analysis was performed using Statistica 10 software. Because the distributions of most variables were significantly different from normal (Shapiro-Wilk test was used to assess whether data obtained were normally distributed), the results were calculated with the use of tests: $\chi^{2}$ test, Kruskal-Wallis ANOVA, Mann-Whitney U-test, univariate, and multivariate analyses. The level of significance was adopted as $p<0.05$.

\section{Results}

Comparison of prognostic factors between group I and II with reference to the outcome $24 \mathrm{~h}$ after rt-PA administration are presented in Tables 1 and 2. Patients from group II more often had hypertension, presence of old ischaemic changes in brain CT, greater baseline neurological deficit, and longer therapeutic window. Both uni- and multivariate analysis confirmed these results with statistically significant values (Tables 3 and 4).

\section{Discussion}

The early effectiveness of intravenous rt-PA administration in stroke patients was analysed in relation to the NIHSS score $24 \mathrm{~h}$ after administration. The outcome on the second day was assessed as an improvement of NIHSS $\geq 2$ points versus other cases. The border of $>1$ point was established to avoid subjective, small intraobserver differences of the physical examination.

In our study the mean onset-to-treatment time was statistically longer and connected with lesser improvement in NIHSS II assessments. It appeared to be an independent risk factor in uni- and multivariate analysis. In other publications it was also presented that the time from the onset of stroke to treatment was connected with a favourable outcome in mRS at day 90 [22-24]. These observations are consistent with the recommendations that every effort should be made to treat patients as early as possible after symptom onset [25]. Of note is that other authors showed no association between the therapeutic window and rapid neurological recovery defined as an improvement $\geq 50 \%$ in NIHSS score within the first $24 \mathrm{~h}$ after rt-PA treatment [10].

Other authors established the factors that have an influence on bad outcomes measured in mRS at 3 months in VENI patients, i.e.: recent TIA, higher baseline NIHSSS, shorter onset-to-needle time, and less frequent pneumonia and malignant infarction [24].

In our study the hypertension was connected with lower frequency of improvement in NIHSS II assessment and was found as an independent risk factor of worse prognosis. In the ECASS study hypertension was also a significant factor affecting the longterm outcome [22]. On the other hand, we observed that the initial values of blood pressure, irrespective of hypertension history, did not affect the outcome. Such a finding seems to be consistent with the recommendations indicating the benefit of maintaining the initial blood pressure at a higher level [6]. The role of blood pressure in thrombolytic treatment was also observed by other authors, which demonstrated that blood pressure variability was associated with greater diffusion-weighted magnetic resonance imaging lesion growth and worse clinical course in patients with stroke treated with rt-PA [16]. Higher initial values of SBP in patients with no history of hypertension were connected with increased risk of SICH secondary to thrombolysis [26]. Patients benefited from rt-PA in terms of no or negligible handicap after 90 days, without excess risk of death, with baseline SBP between 140 and $160 \mathrm{~mm} \mathrm{Hg}$ or baseline DBP between 80 and $90 \mathrm{~mm} \mathrm{Hg}$ [27]. In future studies the impact of blood

Table 1. Comparison of factors between group I and II with reference to the outcome $24 \mathrm{~h}$ after rt-PA administration $\left(p-\chi^{2}\right.$ test $)$

\begin{tabular}{|c|c|c|c|}
\hline Prognostic factor & $\begin{array}{l}\text { Group I } \\
(n=105)\end{array}$ & $\begin{array}{l}\text { Group II } \\
(n=140)\end{array}$ & $P$-value \\
\hline Age [years] & 54-86 (mean: $68.4 \pm 13.31)$ & 45-94 (mean: $71.1 \pm 10.69$ ) & 0.19961 \\
\hline Body mass index $\left[\mathrm{kg} / \mathrm{m}^{2}\right]$ & 27.3-41.6 (mean: $28.3 \pm 4.74)$ & 17.5-41.5 (mean: $29.1 \pm 4.97$ ) & 0.19959 \\
\hline Initial NIHSS & 4-31 (mean: $11.9 \pm 6.44)$ & 3-27 (mean: $15 \pm 6.51)$ & 0.00010 \\
\hline Initial body temperature $\left[{ }^{\circ} \mathrm{C}\right]$ & 36.0-37.7 (mean: $36.4 \pm 1.02$ ) & 36.0-37.6 (mean: $36.5 \pm 0.30)$ & 0.13871 \\
\hline Initial SBP [mm Hg] & 100-230 (mean: $154.3 \pm 27.44)$ & 130-225 (mean: $160.5 \pm 27.92)$ & 0.10745 \\
\hline Initial DBP [mm Hg] & 55-125 (mean: $84.5 \pm 15.72)$ & 60-140 (mean: $85.1 \pm 15.90)$ & 0.67595 \\
\hline Therapeutic window [min] & 40-315 (mean: $173.2 \pm 55.88$ ) & 50-360 (mean: $204.9 \pm 50.27$ ) & 0.00005 \\
\hline CRP $[\mathrm{mg} / \mathrm{ll}]$ & 1-73.8 (mean: $9.9 \pm 22.40)$ & 1-281 (mean: $13.2 \pm 32.08$ ) & 0.72927 \\
\hline Fibrinogen $[\mathrm{mg} / \mathrm{dl}]$ & $186.4-595.9$ (mean: $353.1 \pm 87.65)$ & 147.3-903 (mean: $381.9 \pm 99.57$ ) & 0.98994 \\
\hline
\end{tabular}


Table 2. Comparison of factors between group I and II with reference to the outcome $24 \mathrm{~h}$ after rt-PA administration ( $p$ - Mann-Whitney U-test)

\begin{tabular}{|c|c|c|c|}
\hline Prognostic factor & $\begin{array}{c}\text { Group I } \\
(n=105)\end{array}$ & $\begin{array}{l}\text { Group II } \\
(n=140)\end{array}$ & $P$-value \\
\hline \multicolumn{3}{|l|}{ Sex: } & \multirow{3}{*}{0.74480} \\
\hline Male & $52(49.5 \%)$ & $73(52.1 \%)$ & \\
\hline Female & $53(50.5 \%)$ & 67 (47.9\%) & \\
\hline Weekend & 37 (37.8\%) & 39 (28.1\%) & 0.11521 \\
\hline \multicolumn{3}{|l|}{ Hours of admission: } & \multirow{3}{*}{0.55476} \\
\hline 7.01 a.m. - 10 p.m. & 87 (82.8\%) & $121(86.4 \%)$ & \\
\hline 10.01 p.m. - 7 a.m. & $18(17.2 \%)$ & $19(13.6 \%)$ & \\
\hline \multicolumn{3}{|l|}{ Occupation: } & \multirow{3}{*}{0.30246} \\
\hline White collar & 18 (17.2\%) & $36(25.7 \%)$ & \\
\hline Blue collar & 87 (82.8\%) & $104(74.3 \%)$ & \\
\hline Hypertension & $64(60.9 \%)$ & $109(77.8 \%)$ & 0.02517 \\
\hline Coronary heart disease & $30(28.6 \%)$ & $57(40.7 \%)$ & 0.09590 \\
\hline Myocardial infarction & 15 (14.3\%) & $30(21.4 \%)$ & 0.21861 \\
\hline Atrial fibrillation & $34(32.4 \%)$ & $53(37.9 \%)$ & 0.58894 \\
\hline Diabetes mellitus & $21(21.4 \%)$ & $40(28.6 \%)$ & 0.20256 \\
\hline Smoking & $38(36.2 \%)$ & $37(26.4 \%)$ & 0.54236 \\
\hline Previous stroke/TIA & $10(9.5 \%)$ & 25 (17.9\%) & 0.09195 \\
\hline ICA significant stenosis & 22 (20.9\%) & $36(28.4 \%)$ & 0.36009 \\
\hline Dyslipidaemia & $52(49.5 \%)$ & $66(47.1 \%)$ & 0.60416 \\
\hline Previous antiplatelets & $23(21.9 \%)$ & $41(29.3 \%)$ & 0.29334 \\
\hline Previous anticoagulants & $5(4.8 \%)$ & 14 (10.1\%) & 0.16529 \\
\hline Previous antihypertensives & $47(44.8 \%)$ & $84(60 \%)$ & 0.07100 \\
\hline Old ischaemic changes in initial CT & $19(31.7 \%)$ & $44(51.2 \%)$ & 0.04564 \\
\hline Old and early ischaemic changes in initial CT & $14(37.8 \%)$ & $13(24.1 \%)$ & 0.15800 \\
\hline
\end{tabular}

Table 3. Comparison of prognostic factors between group I and II with reference to the outcome $24 \mathrm{~h}$ after rt-PA administration - univariate regression

\begin{tabular}{|lccc|}
\hline Prognostic factor & $P$-value & Odds ratio & $-\mathbf{9 5 \% ~ C l ; ~ + 9 5 \% ~ C l}$ \\
Hypertension & 0.025 & 0.518 & $0.289 ; 0.928$ \\
Therapeutic window (calculated for 1 min) & $<0.001$ & 0.988 & $0.983 ; 0.994$ \\
Initial NIHSS (calculated for 1 point) & $<0.001$ & 0.924 & $0.886 ; 0.963$ \\
Old ischaemic changes in initial CT & 0.018 & 0.665 & $0.469 ; 0.941$ \\
\hline
\end{tabular}

pressure values and use of hypotensives in rt-PAtreated patients should be more precisely analysed.

We analysed only the period of early hospital treatment, but our results may be used in predicting longterm outcome and potential intensification of treatment in terms of secondary prevention, because, as shown by other authors, rapid neurological recovery is correlated with favourable outcomes assessed by 3-month mRS [10, 14-16]. In another study the day-7/10 mRS was independently and strongly associated with day90 mRS. The authors suggested that functioning after first week, supplemented by initial stroke severity and history information of congestive heart failure, may provide an early outcome guide useful for more intensive and efficient secondary prevention [28]. Disability and mortality at day 90 was also proven to be connected with baseline NIHSS score in other studies $[7,22]$. We obtained similar results regarding baseline 
Table 4. Comparison of prognostic factors between group I and II with reference to the outcome $24 \mathrm{~h}$ after rt-PA administration - multivariate regression

\begin{tabular}{|lccc|}
\hline Prognostic factor & $\boldsymbol{P}$-value & Odds ratio & $\begin{array}{c}\mathbf{- 9 5 \%} \mathrm{Cl} \\
\mathbf{+ 9 5 \%} \mathrm{Cl}\end{array}$ \\
Hypertension & 0.012 & 0.341 & $0.148 ; 0.785$ \\
Therapeutic window (calculated for 1 minute) & 0.002 & 0.988 & $0.981 ; 0.995$ \\
Initial NIHSS (calculated for 1 point) & 0.005 & 0.913 & $0.858 ; 0.972$ \\
Old ischaemic changes in initial CT & 0.004 & 0.554 & $0.369 ; 0.829$ \\
\hline
\end{tabular}

NIHSS score. In our patients a higher score was connected with a worse outcome and appeared to be an important predictor of worse prognosis, which is consistent with other studies [10, 23]. On the other hand, it was presented that VENI patients assessed $1 \mathrm{~h}$ after rt-PA have higher baseline NIHSS score [24]. Interestingly, lower baseline NIHSS was connected with early neurological deterioration [29].

We showed that patients with the presence of old ischaemic changes in the initial brain CT were less likely to gain 24-hour neurological improvement. The role of such findings is not clear, but similar results were presented by other authors - the presence of radiological signs of previous stroke in baseline CT was connected with higher rate of death within 3 months of thrombolysis [7]. This is presumably connected with the presence of evident or clinically silent cerebrovascular disorders in such patients, similarly to the interpretation of white matter hyperintensities [30]. The role of white matter hyperintensities in rt-PA stroke treatment may be of interest in future analyses.

We showed that significant stenosis of the internal carotid artery did not affect the early outcome. Contrary to our results, a recent study comparing the effect of intravenous rt-PA with placebo within the 3-6hour therapeutic window reported that most patients with ICA occlusion did not achieve good clinical outcomes, whether treated with rt-PA or placebo [31]. Internal carotid artery occlusion was independently associated with early neurological deterioration after rt-PA therapy [29]. This suggests that the presence of carotid artery stenosis is not an early prognostic factor in patients treated with rt-PA in opposition to the occlusion of carotid arteries.

We did not find diabetes to be a factor affecting the early outcome. As presented by other authors, higher blood glucose levels are connected with lower grade of early neurological improvement and even with higher risk of early deterioration after rt-PA treatment [10, 29].

Our results indicate that age cannot be used as a prognostic factor of early improvement in thrombolytic treatment. This is inconsistent with other studies that indicated younger age as a significant predictor of good early and long-term outcome [7, 10, 32].
The limitation of our study is the small sample size and the fact that the analysis was performed as a single-centre study.

\section{Conclusions}

There are factors affecting the grade of early neurological improvement assessed $24 \mathrm{~h}$ after rt-PA therapy, which should be taken into consideration in the acute phase treatment and secondary prevention of thrombolysed stroke patients. The group of patients that should be of special interest during the hospitalisation are those with hypertension, greater initial neurological deficit, longer onset-to-treatment time, and old ischaemic changes in initial brain CT.

\section{Conflict of interest}

The authors declare no conflict of interest.

\section{References}

1. The National Institute of Neurological Disorders and Stroke rt-PA Stroke Study Group. Tissue plasminogen activator for acute ischemic stroke. N Engl J Med 1995; 333: 1581-1587.

2. Koudstaal PJ, Stibbe J, Vermeulen M. Fatal ischaemic brain oedema after early thrombolysis with tissue plasminogen activator in acute stroke. BMJ 1988; 297: 1571-1574.

3. Wardlaw JM, Murray V, Berge E, Del Zoppo GJ. Thrombolysis for acute ischaemic stroke. Cochrane Database Syst Rev 2009; 4: CD000213.

4. Saver JL. Number needed to treat estimates incorporating effects over the entire range of clinical outcomes: novel derivation method and application to thrombolytic therapy for acute stroke. Arch Neurol 2004; 61: 1066-1070.

5. Toyoda K, Koga M, Naganuma M, Shiokawa Y, Nakagawara J, Furui E, Kimura K, Yamagami H, Okada Y, Hasegawa Y, Kario K, Okuda S, Nishiyama K, Minematsu K; Stroke Acute Management with Urgent Risk-factor Assessment and Improvement Study Investigators. Routine use of intravenous low-dose recombinant tissue plasminogen activator in Japanese patients: general outcomes and prognostic factors from the SAMURAI register. Stroke 2009; 40: 3591-3595.

6. Adams HP Jr, del Zoppo G, Alberts MJ, Bhatt DL, Brass L, Furlan A, Grubb RL, Higashida RT, Jauch EC, Kidwell C, Lyden PD, Morgenstern LB, Qureshi AI, Rosenwasser RH, Scott PA, Wijdicks EF; American Heart Association; American Stroke Association Stroke Council; Clini- 
cal Cardiology Council; Cardiovascular Radiology and Intervention Council; Atherosclerotic Peripheral Vascular Disease and Quality of Care Outcomes in Research Interdisciplinary Working Groups. Guidelines for the early management of adults with ischemic stroke: a guideline from the American Heart Association/American Stroke Association Stroke Council, Clinical Cardiology Council, Cardiovascular Radiology and Intervention Council, and the Atherosclerotic Peripheral Vascular Disease and Quality of Care Outcomes in Research Interdisciplinary Working Groups: the American Academy of Neurology affirms the value of this guideline as an educational tool for neurologists. Stroke 2007; 38: 1655-1711.

7. Sobolewski P, Sledzińska-Dźwigał M, Szczuchniak W, Hatalska-Żerebiec R, Grzesik M, Sobota A. The efficacy and safety of intravenous thrombolysis with alteplase in the treatment of ischaemic stroke in a rural hospital. Neurol Neurochir Pol 2013; 47: 310-318.

8. Hong KS, Saver JL. Years of disability-adjusted life gained as a result of thrombolytic therapy for acute ischemic stroke. Stroke 2010; 41: 471-477.

9. Muscari A, Puddu GM, Santoro N, Zoli M. A simple scoring system for outcome prediction of ischemic stroke. Acta Neurol Scand 2011; 124: 334-342.

10. Machumpurath B, Davis SM, Yan B. Rapid neurological recovery after intravenous tissue plasminogen activator in stroke: prognostic factors and outcome. Cerebrovasc Dis 2011; 31: 278-283.

11. Dharmasaroja PA, Muengtaweepongsa S, Dharmasaroja P. Early outcome after intravenous thrombolysis in patients with acute ischemic stroke. Neurol India 2011; 59: 351-354.

12. Rangaraju S, Frankel M, Jovin TG. Prognostic value of the 24-hour neurological examination in anterior circulation ischemic stroke: a post hoc analysis of two randomized controlled stroke trials. Interv Neurol 2016; 4: 120-129.

13. Balucani C, Levine SR, Khoury JC, Khatri P, Saver JL, Broderick JP. Acute ischemic stroke with very early clinical improvement: a national institute of neurological disorders and stroke recombinant tissue plasminogen activator stroke trials exploratory analysis. J Stroke Cerebrovasc Dis 2016; 25: 894-901.

14. Yeo LL, Paliwal P, Teoh HL, Seet RC, Chan BP, Wakerley B, Liang S, Rathakrishnan R, Chong VF, Ting EY, Sharma VK. Early and continuous neurologic improvements after intravenous thrombolysis are strong predictors of favorable long-term outcomes in acute ischemic stroke. J Stroke Cerebrovasc Dis 2013; 22: e590-e596.

15. Hemmen TM, Ernstrom K, Raman R. Two-hour improvement of patients in the National Institute of Neurological Disorders and Stroke trials and prediction of final outcome. Stroke 2011; 42: 3163-3167.

16. Muresan IP, Favrole P, Levy P, Andreux F, Marro B, Alamowitch S. Very early neurologic improvement after intravenous thrombolysis. Arch Neurol 2010; 67: 1323-1328.

17. Takagi T, Kato T, Sakai H, Nishimura Y. Early neurologic improvement based on the National Institutes of Health Stroke Scale score predicts favorable outcome within 30 minutes after undergoing intravenous recombinant tissue plasminogen activator therapy. J Stroke Cerebrovasc Dis 2014; 23: 69-74.

18. Guettier S, Cogez J, Bonnet AL, Dean P, Apoil M, Tchoumi T, Dubuc L, Arzur J, de la Sayette V, Kouassi LK, Via- der F, Touzé E. Factors associated with timing of early neurological improvement after thrombolysis for ischaemic stroke. Eur J Neurol 2016; 23: 664-667.

19. Ong CT, Sung SF, Wu CS, Hsu YC, Su YH, Li CH, Hung LC. Early neurological improvement after intravenous tissue plasminogen activator infusion in patients with ischemic stroke aged 80 years or older. J Chin Med Assoc 2014; 77: 179-183.

20. Brott T, Adams HP, Olinger CP, et al. Measurements of acute cerebral infarction: a clinical examination scale. Stroke 1989; 20: 864-870.

21. Kotlęga D, Białecka M, Kurzawski M, Droździk M, Ciećwież S, Gołąb-Janowska M, Nowacki P. Risk factors of stroke and 717A > G (rs2794521) CRP gene polymorphism among stroke patients in West Pomerania province of Poland. Neurol Neurochir Pol 2014; 48: 30-34.

22. Hacke W, Kaste M, Bluhmki E, Brozman M, Dávalos A, Guidetti D, Larrue V, Lees KR, Medeghri Z, Machnig T, Schneider D, von Kummer R, Wahlgren N, Toni D; ECASS Investigators. Thrombolysis with alteplase 3 to 4.5 hours after acute ischemic stroke. N Engl J Med 2008; 359: 13171329.

23. Apoil M, Turc G, Tisserand M, Calvet D, Naggara O, Domigo V, Baron JC, Oppenheim C, Touzé E. Clinical and magnetic resonance imaging predictors of very early neurological response to intravenous thrombolysis in patients with middle cerebral artery occlusion. J Am Heart Assoc 2013; 2: e000511.

24. Bodenant M, Debette S, Cordonnier C, Dumont F, Hénon $\mathrm{H}$, Bordet R, Leys D. A very early neurological improvement after intravenous thrombolysis for acute cerebral ischaemia does not necessarily predict a favourable outcome. Acta Neurol Belg 2013; 113: 67-72.

25. Ahmed N, Wahlgren N, Grond M, Hennerici M, Lees KR, Mikulik R, Parsons M, Roine RO, Toni D, Ringleb P; SITS investigators. Implementation and outcome of thrombolysis with alteplase 3-4.5 h after an acute stroke: an updated analysis from SITS-ISTR. Lancet Neurol 2010; 9: 866-874.

26. Mazya M, Egido JA, Ford GA, Lees KR, Mikulik R, Toni D, Wahlgren N, Ahmed N, Wahlgren N, Dávalos A, Ford GA, Grond M, Hacke W, Hennerici M, Kaste M, Lees KR, Mikulik R, Roine R, Tatlisumak T, Toni D, Wang KS. Predicting the risk of symptomatic intracerebral hemorrhage in ischemic stroke treated with intravenous alteplase: Safe Implementation of Treatments in Stroke (SITS) symptomatic intracerebral hemorrhage risk score. Stroke 2012; 43: 1524-1531.

27. Yong M, Diener HC, Kaste M, Mau J. Long-term outcome as function of blood pressure in acute ischemic stroke and effects of thrombolysis. Cerebrovasc Dis 2007; 24: 349-354.

28. Ovbiagele B, Saver JL. Day-90 acute ischemic stroke outcomes can be derived from early functional activity level. Cerebrovasc Dis 2010; 29: 50-56.

29. Mori M, Naganuma M, Okada Y, Hasegawa Y, Shiokawa Y, Nakagawara J, Furui E, Kimura K, Yamagami H, Kario K, Okuda S, Koga M, Minematsu K, Toyoda K. Early neurological deterioration within 24 hours after intravenous rt-PA therapy for stroke patients: the stroke acute management with urgent risk factor assessment and improvement rt-PA registry. Cerebrovasc Dis 2012; 34: 140146. 
30. Kotlęga D, Gołąb-Janowska M, Masztalewicz M, Ciećwież S, Nowacki P. The emotional stress and risk of ischemic stroke. Neurol Neurochir Pol 2016; 40: 265-270.

31. De Silva DA, Brekenfeld C, Ebinger M, Christensen S, Barber PA, Butcher KS, Levi CR, Parsons MW, Bladin CF, Donnan GA, Davis SM; Echoplanar Imaging Thrombolytic Evaluation Trial (EPITHET) Investigators. The benefits of intravenous thrombolysis relate to the site of baseline arterial occlusion in the Echoplanar Imaging Thrombolytic Evaluation Trial (EPITHET). Stroke 2010; 41: 295-299.

32. Chindaprasirt J, Sawanyawisuth K, Chattakul P, Limpawattana P, Tiamkao S, Aountri P, Chotmongkol V. Age predicts functional outcome in acute stroke patients with rt-PA treatment. ISRN Neurol 2013; 2013: 710681.

\section{Address for correspondence:}

Dariusz Kotlęga MD, PhD

Department of Neurology

Pomeranian Medical University

ul. Unii Lubelskiej 1, 71-252 Szczecin, Poland

Phone: +48 914253251

E-mail: dkotlega@poczta.onet.pl 